\title{
The Evaluation of the Social Studies Curriculum in Turkey: The Guiding Principle of Balance
}

Gurbuz Ocak, Prof.Dr.

Afyon Kocatepe University, Turkey

Akin Karakuyu, Lecturer

Hatay Mustafa Kemal University, Turkey

Doi:10.19044/ejesvv8no2a68

URL:http://dx.doi.org/10.19044/ejes.v8no2a68

Submitted: 14 April 2021

Accepted: 08 May 2021

Published: 30 June 2021
Copyright 2021 Author(s)

Under Creative Commons BY-NC-ND

4.0 OPEN ACCESS

\begin{abstract}
:
This study investigates the social studies curriculum applied in 4th 5th 6th and 7th grades in Turkeyaccording to the principle of balance, which is one of the guiding principles of curriculum development. The research is conducted with a case study of qualitative research methods. The research is designed with a holistic case study design. Research data were collected by the methods of the interview with social studies teachers, observation in 4th 5th 6th and 7th grades and document review of the course objectives in the social studies curriculum and analyzed by content analysis technique. The reliability of the data was calculated with the multi-degree Kappa coefficient based on the agreement between the observers and the opinion agreement for the opinions. According to the results of the study, it was found out the principle of balance was generally neglected, and there is balance with regards to the past and present, different cultures and local culture, close and distant environment, classroom and out-of-class learning while there is no balance in terms of using only written, verbal and visual materials and the other principles. The research consequently suggested recommendations to curriculum development experts and teachers to ensure the principle of balance.
\end{abstract}

Key Words: Principle of Balance, Curriculum Evaluation, Social Studies Curriculum

\section{Introduction:}

The main purpose of the curriculum is to design the course levels according to the school levels and reveal the potential of individuals in all areas in a balanced way and enable them to acquire new skills.

A curriculum is a series of learning products that enable decision-making in both teaching and evaluation, or the planning or design of the entire content to be taught with the goals and evaluation dimensions of a field (Posner, 1995, p.5). The instructional program, on the other hand, is a program that consists of certain knowledge categories and aims at teaching knowledge and skills in a planned manner in line with the objectives set in the curriculum by focusing on skills and practice in some schools (Küçükahmet, 2009, p.9).

Today, developments in knowledge, science, and technology affect the education system, making it necessary to rearrange curriculum from time to time and adapt them according to the conditions 
of the day. The curriculum development process is a multidimensional and continuousprocess consisting of planning, design, pre-application, and evaluation stages (Khan \& Law, 2015, p.67). The first step of this process is to design the curriculum. According to Adigüzel (2017), thepurpose, content, educational attainments, and assessment dimensions to be included in the curriculum at the draft stage are arranged logically and systematically.

There are some principles in the curriculum design process. According to Yücel et al. (2017, p.707), these principles are scope, progressiveness, continuity, cohesion, balance, usability, and flexibility. Besides, Hewitt (2006) listed curriculum design principles as scope, progressivity, continuity, and balance. According to Ornstein and Hunkins (2016), curriculum design principles are scope, sequence, continuity, integration, harmony, and balance.

According to the principle of balance, students should be allowed to use and internalize what they have learned, taking into account their mental, personal, and social development (Doğanay, 2008, p.23). Balance means ensuring the adaptation of the sometimes complex curriculum with the students' developmental levels (Hewitt, 2006). When designing a curriculum, educators attempt to give equal weight to each feature of the design as required by the principle of balance. In a balanced curriculum, students gain the opportunity to acquire and use knowledge in personal, social, and intellectual ways (Ornstein \& Hunkins, 2016, p.256).

The aim of designing a balanced curriculum in schools is to firstly develop students' artistic aspects such as social, sports, and music and discover their skills and secondly, to improve their academic performance, and thirdly, to balance their learning outside the school (Kibet, 2016). A balanced curriculum also had positive results on student achievement (Squires, 2013). Galton (2000, p.16) stated that one of the four questions to be asked for the success of the curriculum implemented at the national level is how broad and balanced curriculum can be ensured. Porter (1989) stated in his study titled "An unbalanced curriculum: example of primary school mathematics" that teachers could not know what they taught in an unbalanced curriculum and that success was left up to chance.

A balanced curriculum is important for the multifaceted development of students. It offered three alternatives to create a balance in a better program. The first is that the learning objectives are aimed at basic concepts and skills, the second is to ensure a balance in in-school and out-ofschool interaction and the third is to balance between subject-centered traditional education and meaningful, autonomous and activity-based education (Akker, 201, p.42).

In the studies on design principles in the literature, the information and technologies curriculum (Geçitli and Bümen, 2020), the foreign language-weighted 5th grade English curriculum (Canlıer \& Bümen, 2018) and Primary and Secondary English curricula (Yücel, Dimici, Y1ldız and Bümen, 2017) were previously investigated. When the studies on the social studies curriculum are examined, there are primarily studies focusing on the opinions about the curriculum and the comparisons of previous social studies curricula with the current one (Çakmak, Kaçar and Arıkan, 2017; Gürel, 2017; Taş and Kıroğlu, 2018; Sözen and Ada, 2018; Yıldız and K1lıç, 2018). There is no study examining the social studies curriculum in terms of design principles. In this study, the principle of balance, one of the principles of social studies curriculum design, was thoroughly examined to fill this gap in the literature.

The research was conducted based on 17 principles suggested by Oliva and Gordon II (2018, p.468-470) to achieve balance in the curriculum. These principles are as follows:

1- Student-centered and subject-centered curriculum,

2- The balance between the students' and society's needs

3- General and customized education balance,

4- Balance between width and depth in content,

5- Establishing a balance between cognitive, affective, and psychomotor development areas, 
6- Establishing a balance between individualized education and general education,

7- Ensuring a balance between innovation and tradition,

8- Balance between the logic of the subject and the student's learning psychology,

9- Balance between the needs of extraordinary and non-extraordinary students,

10- Balance in terms of the needs of different students in terms of intelligence,

11- Balance between written, verbal, and visual techniques and materials,

12- Balance between near and far in terms of time and environment,

13- Balance between academic aspects, entertainment, and physical activities,

14- Balance between in-school and out-of-school learning,

15- Balance between disciplines,

16- Balance between curriculum,

17- Balance within the disciplines.

Developing a balanced curriculum is extremely important, as balancing the curricula enables students to develop in many aspects. For this reason, this study evaluates the social studies curriculum based on the principle of balance and seeks answers to the following questions:

\section{Problem Statement:}

How is the principle of "balance" as one of the principles of curriculum design reflected in the social studies curriculum?

\section{Sub-Problems:}

How is the principle of balance reflected in the social studies curriculum from the following aspects?

1- Being student-centered or subject-centered,

2- Meeting the needs of students and society,

3- Among the sub-branches of the course (history, geography, citizenship),

4- Distribution of goals to cognitive, affective, and psychomotor domains,

5- Suitability for group learning and individualized learning,

6- Compliance of the content with the logic of the subjects and students,

7- The suitability to the students' intelligence level (high, average, etc.),

8- Use of written, verbal, and visual techniques,

9- Including academic aspects, sports, entertainment, and physical activities,

10- Providing opportunities for in-class and out-of-class learning,

11- Compliance with different disciplines,

12- Allowing different learning approaches,

13- Appropriateness to students' development level

14- Being open to innovations and being tradition-bound,

15- Compliance with the near and far and past and current developments

\section{METHOD}

\section{Research Model:}

This study, which examined in depth the suitability of the social studies curriculum to the principle of balance, which is one of the principles of curriculum development, was conducted as a case study from qualitative research methods. Case studies are a qualitative approach concerning real life in which the researcher deals with a situation and collects detailed and in-depth data on 
this case (Creswell, 2007, p.97). The qualitative research model used to find answers to scientific questions and seen as a distinctive approach is called a case study (Büyüköztürk et al., 2011, p.273). If a single unit of analysis is used in case studies and its specific situations are studied, a holistic case study design is used (Yin, 2014). In this study, since the social studies curriculum is considered as a curriculum and a single case is analyzed, the holistic case study design is used.

The case study design in the study includes the following stages, respectively:

1- Examination of the course objectives in the Social Studies curriculum

2- Conducting semi-structured interviews with social studies teachers according to the balance principles determined by Olivia and Gordon II (2018)

3- Observation by using co-observes,

4- Analysis of data obtained from three data collection tools,

5- Interpretation of the obtained findings.

\section{Data Collection Tools:}

The research data were collected by using data triangulation with observation, interview, and document review techniques.

Semi-Structured Interview Form: The interview form consists of 15 open-ended questions prepared for primary school teachers teaching 4th grades and social studies teachers. The researchers prepared the questions within the framework of the principles determined to ensure the balance in the curriculum by Olivia and Gordon II (2018). The questions were revised by submitting them to three experts in the field of education curriculum and teaching. The interviews were conducted with 8 teachers.

Observation Checklist: The checklist was created by the researchers, considering the balance principles suggested by Olivia and Gordon II (2018), and was finalized by submitting to the opinion of three experts in the education curriculum and education field. The observation form consists of 18 items. The items were graded from 1 to 3 from insufficient to sufficient. The observations lasted for 4 weeks, in the form of 2 lesson hours for the 4 th grades and 3 lesson hours for the 5th, 6th, and 7 th grades.

Document: In the study, 131 objectives included in the social studies curriculum updated in 2018 by the Ministry of National Education were examined as documents to determine to what extent the principles of balance are reflected in the social studies course curriculum.

Data Analysis:

Content analysis was used to analyze the opinions collected from the teachers in the analysis of the data. In the content analysis, opinion agreement among researchers was determined using Miles and Huberman's (1994) opinion agreement formula. In the analysis of the data obtained through observation, the observation forms created as a result of the observation made with the co-observer were analyzed using the multi-degree Kappa coefficient formula, and the document analysis was analyzed with the content analysis technique. The Kappa test is a statistical method that measures the reliability of the agreement between two or more observers regarding the phenomenon they observe. The Kappa coefficient formula is $\operatorname{Pr}(\mathrm{a})-\operatorname{Pr}(\mathrm{e}) / 1-\operatorname{Pr}(\mathrm{e})$. Here, $\operatorname{Pr}(\mathrm{a})$ refers to the observed agreement, and $\operatorname{Pr}(\mathrm{e})$ to the probability of random agreement (Cohen, 1960 as cited in Kilıç, 2015, p.142). In the observation form used in the study, the scoring was 3-graded in the form of 1-2-3, and the multi-degree Kappa coefficient was used instead of the two-degree Kappa coefficient. The Kappa formula applied in this method is the same as the Kappa formulas applied in the two-degree method. However, the data matrix is not in the form of $2 \times 2$, and the number of matrices is determined by the number of degrees in the form of $3 \times 3$ or $4 \times 4$ (Şencan, 
2005, p.488).

The interpretation of the Kappa coefficient according to the result is as follows (Şencan, 2005, p. 485)

1- Slight agreement $=<0.20$

2- Fair agreement $=0.20-0.40$

3- Moderate agreement $=0.40-0.60$

4- Substantial agreement $=0.60-0.80$

6- Almost perfect agreement $=0.80-1.00$

\section{Validity - Reliability:}

Since the validity and reliability of the case studies are the subjects of criticism, and they are regarded as one of their weaknesses, data diversification was used to increase the validity of the study. In this context, the data were collected by examining the lesson observations with the co-observer, face-to-face interviews with the teachers, and the examination of the curriculum objectives using the document technique. The teacher interview form and observation form prepared by the researchers were presented to the opinions of three experts from the curriculum and education field and revised the consequent form to increase the reliability of the study. Besides, while observing in the learning-teaching process, observations were made with a co-observer who received doctorate education in curriculum and teaching.

For the reliability of the data obtained from the teachers using the semi-structured interview technique, the opinion agreement formula of Miles and Huberman (1994) was used. This agreement is formulated as "Opinion agreement $=($ Consensus / Disagreement + Consensus $) *$ 100." The opinion agreement on teachers' opinions in the study was calculated as $83.33 \%$. According to Miles and Huberman (1994) and Patton (2002), the consensus between coders is expected to be at least $80 \%$.

According to the Kappa Test, the rate of agreement of the opinions expressed by the observers in the observation form for the observation results is as follows:

The observed agreement rate for 4th Grade is $\operatorname{Pr}(\mathrm{a})=14 / 18=.77$

The observed agreement rate for 5 th Grade is $\operatorname{Pr}(a)=15 / 18=.83$

The observed agreement rate for 6 th Grade is $\operatorname{Pr}(\mathrm{a})=15 / 18=.83$

The observed agreement rate for 7 th Grade is $\operatorname{Pr}(a)=14 / 18=.77$

\section{FINDINGS}

Table 1: Opinions about the Focus of the Curriculum

\begin{tabular}{lll}
\hline Theme & Category & Frequency \\
\hline \multirow{3}{*}{ The Focus of the Curriculum } & Student-Centered & 1 \\
\cline { 2 - 3 } & & Subject-Centered \\
& & 7
\end{tabular}

In the interviews with the teachers, there are opinions that the curriculum is subject-centered $(\mathrm{f}=7)$. Some of the teachers' opinions are as follows:

"Although it seems to be student-centered, when we have a general perspective, it is subject-centered, especially in a history course, which is a sub-branch of social studies." (T2)

"The curriculum was tried to be designed as student-centered, but the sequence and level of the content cannot catch the students' interest." (T5)

"I think it is subject-centered. There is a lot of lecture and content. The number of activities is very low." 
(T8)

"Curriculum and activities are generally student-centered, but the teacher must have certain competencies to be able to do these activities." (T6)

When the curriculum objectives are examined, findings that confirm these opinions were accessed. In the observation made with the co-observer, the observers marked an inadequate option in the checklist. In this sense, it is seen that the curriculum is more subject-centered regarding its focus and is not in a balance in terms of being student and subject-centered.

Table 2: Opinions Regarding the Curriculum's Meeting the Needs

\begin{tabular}{|c|c|c|c|}
\hline Theme & & Category & Frequency \\
\hline \multirow{2}{*}{$\begin{array}{l}\text { Curriculum's } \\
\text { Needs }\end{array}$} & \multirow[t]{2}{*}{ Meeting the } & For Student Needs & 2 \\
\hline & & For Social Needs & 6 \\
\hline
\end{tabular}

In the interviews with the teachers, it is predominant that the curriculum is more oriented towards the needs of the society in terms of the needs of the students and the society $(f=6)$. Some of the opinions of teachers are as follows:

"The needs of the society were met in matters such as homeland, nation, and homeland love, but it is not enough for the respect, responsibility, and values that individuals need." (T1)

"In the curriculum, issues related to adaptation to society are taught by introducing our culture to students, while the needs of the society are met, the needs of individuals are neglected." (T6)

"There are deficiencies in meeting the needs of the students. We cannot take teaching out of the classroom. This is at the discretion of the teacher. Social needs, on the other hand, were met to a great extent." (T8)

When the social studies course objectives were examined, only one objective, which is the balance between subject and society needs, was determined. As the social studies course is perceived as preparing students for society, it can be suggested that the needs of the society are important, and there is no balance in terms of student and society needs in this sense.

Table 3: Opinions Regarding Balance Among Sub-Branches of the Course

\begin{tabular}{lll}
\hline Theme & Category & Frequency \\
\hline Balance Among & Balanced in Sub-Branches of the Course & 3 \\
\cline { 2 - 3 } $\begin{array}{l}\text { Sub-Branches of } \\
\text { the Course }\end{array}$ & $\begin{array}{l}\text { Not Balanced in Sub-Branches of the } \\
\text { Course }\end{array}$ & 5 \\
\hline
\end{tabular}

In the interviews with the teachers, the opinions that the curriculum does not have a balance between the sub-branches of the social studies course, such as history, geography, and citizenship, are more prevalent $(\mathrm{f}=5)$. The following are some of the opinions of teachers:

"There is absolutely no balanced distribution. Citizenship and democracy have little weight in general. History is more weighted than the others. The teaching of geography subjects is insufficient." (T5)

"There is the main focus on citizenship. In particular, the field of geography is included in only one theme. I do not think it is balanced." (T6)

"The content is not evenly distributed with its sub-branches. Citizenship subjects were mentioned in a limited way. There are unnecessary details for the field of geography that will not be useful for 4th-grade students." (T7)

"The distribution seems sufficient in terms of the sub-branches of the course, although some courses seem to come to the fore when we look at the whole, we can say that there is balance. (T4)

When the objectives in the social studies curriculum are examined, it is seen that there are mostly objectives in the field of history and very limited objectives in the field of geography. 
Table 4: Opinions on the Distribution of Goals to Cognitive, Affective, and Psychomotor Areas

\begin{tabular}{lll}
\hline Theme & Category & Frequency \\
\hline Balance Regarding & Balanced & 1 \\
\cline { 2 - 3 } Distribution of Goals & Not Balanced & 7 \\
\hline
\end{tabular}

The psychomotor area is almost non-existent. In this sense, according to the teachers' opinions in the curriculum, the principle of balance in objectives was violated $(f=7)$. Some of the opinions of the teachers are as follows:

"In general, very little space was given to the psychomotor area at the cognitive and affective level." (T2)

"More emphasis was placed on the cognitive area, and not much was on the affective and psychomotor areas." (T6)

"The distribution of the curriculum to the cognitive and affective domains is generally good. However, it is missing in the psychomotor area. In order to develop it, studies on individual motor skills should be included." (T7)

"The cognitive field is more dominant, but this is only at the level of knowledge. There is almost no place given to psychomotor learning more than the affective field psychomotor field." (T8)

Considering the curriculum's objectives, it was determined that the educational situations were more oriented to conveying information during the lesson observations, in which cognitive objectives were predominantly included due to the characteristics of the field of social studies.

Table 5: Opinions on the Suitability for Group Learning and Individualized Learning

\begin{tabular}{llll}
\hline Theme & Category & Frequency \\
\hline Suitability for Group & Suitable for Individual Learning & 1 \\
\cline { 3 - 4 } Learning and Individualized & Suitable for Group Learning & 7 \\
Learning & & & \\
\hline
\end{tabular}

According to teacher's opinions, it can be said that the social studies curriculum is suitable for group learning rather than individualized learning $(\mathrm{f}=6)$. Some of the opinions of the teachers are as follows:

"Some objectives were attempted to be given through the student examples. Although this situation seems appropriate for individualized teaching, it can make it difficult to learn the subject in general terms." (T3)

"I do not think that it is not very suitable for students who need individualized teaching because their interests, abilities, and needs differ." (T4)

"There are some objectives and activities for individualized teaching, but they can be increased a little more." (T6)

"I do not think it is very suitable for individualized learning, although it seems appropriate when we look at the curriculum, the situation is different in practice." (T5)

When the objectives in the curriculum are examined, the objectives that include individualized education are limited. During the observations, co-observers determined that the teachers could not include individualized education to teach the objectives in the determined period. In this sense, it can be said that the principle of balance was violated.

Table 6: Opinions on the Compliance of the Content with the Logic of the Subjects and Students

\begin{tabular}{lll}
\hline Theme & Category & Frequency \\
\hline Compliance of the Content & Student's Logic & 2 \\
\hline
\end{tabular}


and Students

Based on the opinions received from the teachers, it can be said that the content, which is one of the basic elements of the social studies curriculum, is prepared mainly by considering the features of the subject $(\mathrm{f}=6)$. In the observations, it was determined that the teachers tried to adapt the abstract points to student logic by supporting them with materials and examples. Some of the opinions of the teachers are as follows:

"Even if there is no problem in the compliance of the subjects with the logic, the students can be prone to logic by increasing the examples according to the economic, social, and cultural environment of each student." (T1)

"The content is given a lot of unnecessarily extended details. Instead, it can be adapted to the logic of the student with a simpler and concrete content." (T3)

"The content items in the curriculum are in line with the logic of the subjects but do not appeal to the logic of the student. Due to the nature of the course, there are many different sub-branches, so content can appear like many stacking." (T4)

"The content design is absolutely negative. There is no continuity between subjects. There is a sequence that skips from branch to branch. The student has a hard time connecting. Course hours should be increased, and the subjects of History, Geography, and Citizenship should be given systematically and chronologically." (T5)

"I do not think there is any problem in terms of compliance with the logic of the students in general. Some of the concepts can remain abstract, and they can be arranged by making arrangements about them." (T7)

Table 7: Opinions on the Suitability to the Students' Intelligence Level (high, average, etc.)

\begin{tabular}{lll}
\hline Theme & Category & Frequency \\
\hline $\begin{array}{l}\text { Suitability to the Students' } \\
\text { Intelligence Level }\end{array}$ & Suitable for Different Types of Intelligence & 2 \\
\cline { 2 - 3 } & Not Suitable for Different Types of Intelligence & 6 \\
\hline
\end{tabular}

According to the opinions of teachers' it can be suggested that although the social studies curriculum is sufficient to meet the needs of average and upper-level students, it is not sufficient for the needs of lower-level students $(\mathrm{f}=6)$.

"We can say that the student level in the social studies course is generally the closest to the homogeneous. There is not much problem in meeting student needs." (T1)

"There are appropriate objectives to meet the needs of both average and high-level students. (T6)

"It meets the needs of normal students sufficiently. But I think it is a bit lacking for high-level students." (T7)

"Normal and high-level students understand basic level concepts that they will need in daily life, but lower-level students have difficulties." (T8)

When the objectives in the curriculum are examined, it can be indicated that different individual characteristics of individuals with different intelligence types are considered in the curriculum, but in the observations conducted in this study, teachers adopt a standard approach more than students with average intelligence levels.

Table 8: Opinions on the Use of Written, Verbal, and Visual Techniques

\begin{tabular}{lll}
\hline Theme & Category & Frequency \\
\hline The Use of Written, & Suitable for Different Types of & 8 \\
\hline
\end{tabular}




\begin{tabular}{lll}
\hline Verbal, and Visual & Techniques & \\
\cline { 2 - 2 } Techniques & $\begin{array}{l}\text { Not Suitable for Different Kinds of } \\
\text { Techniques }\end{array}$ \\
\hline
\end{tabular}

According to the teachers' opinions, the social studies curriculum is a field where these techniques can be used together in the written, verbal, and visual sense, and a balance was achieved in this regard ( $\mathrm{f}=8)$. Some of the teachers' opinions on this issue are as follows:

"Cognitive level objectives also necessarily need written and visual support in affective level gains. It is positive that the textbook pictures are real pictures to make them concrete. Its use depends mostly on the research ability of the teacher." (T3)

"It is appropriate in terms of written, verbal and visual, but needs to be further enriched in terms of visual techniques. Visual elements are more suitable for children at this age, especially for their level." (T4)

"It is naturally not appropriate to use these techniques in every theme. However, if we consider the curriculum in general, it is balanced in terms of the use of each of these techniques in terms of achieving the objectives." (T6)

When the objectives in the social studies curriculum are examined and in the observations made, it can be said that different written, verbal, and visual techniques are used by teachers, and the principle of balance is included in the curriculum.

Table 9: Opinions on the Balance between Academic Aspects, Entertainment, and Physical Activities

\begin{tabular}{llll}
\hline Theme & Category & Frequency \\
\hline Balanced between Academic & Balanced between Academic Aspects, 1 \\
Aspects, Entertainment, and & Entertainment, and Physical Activities & \\
\cline { 2 - 4 } Physical Activities & $\begin{array}{l}\text { Not Balanced between Academic Aspects, } \\
\text { Entertainment, and Physical Activities }\end{array}$ & \\
\hline
\end{tabular}

According to the teachers' views, there is no balance between the social studies curriculum in terms of academic aspects, sports, entertainment, and physical activities $(\mathrm{f}=7)$. Some of the teachers' opinions on this sub-problem are as follows:

"The balance between the academic aspect and sports, entertainment and physical activities is insufficient. If more opportunities are offered to schools, more active learning could occur." (T4)

"Not only in terms of social studies, but all other curricula are lacking in this regard, there is an artificial understanding of art and limited sports activities." (T5)

"Activities such as trips, observations, and research within the scope of the curriculum ensure the harmony between these activities." (T6)

"There is content that supports these activities. However, in general, this fit can be further increased. In order for learning to be more permanent, physical activity adaptation should be given more place." (T7)

When the objectives in the curriculum were examined, there was no one that included academic aspects, sports, entertainment, and physical activities. Besides, during the observations, it was observed that teachers did not give much place to these activities. In this context, the curriculum is not suitable for the principle of balance in terms of academic aspects, sports, entertainment, and physical activity.

Table 10: Opinions on the Balance of the Curriculum in Providing Opportunity for In-Class and Out-Class Learning 


\begin{tabular}{lll}
\hline & $\begin{array}{l}\text { Balanced in Providing Opportunity for In-Class } \\
\text { Providing Opportunity for In- }\end{array}$ \\
\cline { 2 - 3 } Class and Out-Class Learning & $\begin{array}{l}\text { Not Balanced in Providing Opportunity for In- } \\
\text { Class and Out-of-Class Learning }\end{array}$ \\
\hline
\end{tabular}

According to teachers' opinions, although there is a balance in the social studies curriculum in terms of providing in-class and out-of-class learning, it is dependent on some external factors rather than the curriculum in out-of-class learning $(\mathrm{f}=6)$. In the observations, it was found out that teachers teach out-of-class mostly through homework. Some of the teachers' opinions on this sub-problem are as follows:

"The content of the subjects as well as in the classroom can give allow them to learn outside the classroom. In fact, unlike many lessons, the content of the lesson is in the way of making use of events outside the classroom visually." (T1)

"There are usually in-class activities. This situation depends on the socio-economic status of the school and the teacher's devotion rather than the curriculum." (T2)

"Actually, there is a curriculum that provides many opportunities, but external factors such as space, economy, and socio-cultural structure are more effective." (T5)

"There are more in-class activities in the curriculum; if the teacher gives individual out-of-class activities that support the in-class learning of the students, the learning is carried out of the classroom." (T6)

"The information in the content supports the research direction of the students. Especially it provides an opportunity for learning outside the classroom." (T7)

Table 11: Opinions on the Balance of the Curriculum in Terms of Compliance with Different Disciplines

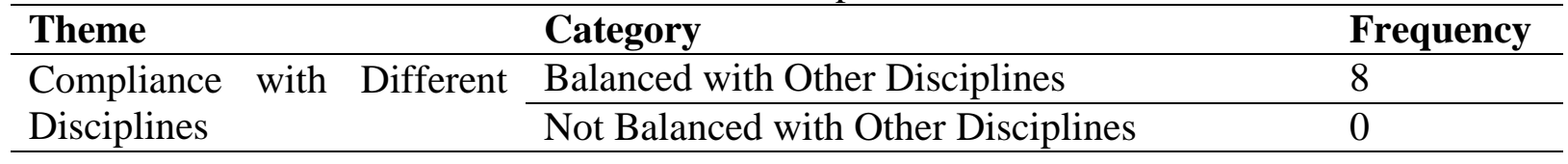

According to the opinions obtained from the teachers, the social studies course is related to other disciplines as it is a core field, and a balance was established between them $(f=8)$. Some of the teachers' opinions on this sub-problem are as follows:

"Social studies course is a flexible course, and by using this flexibility in the curriculum, this balance was achieved with other courses and discipline areas." (T5)

"We can say that the objectives of the primary school 4th-grade social studies curriculum are compatible with mathematics, science, and Turkish courses." (T6)

"The social studies lesson curriculum is associated with Turkish, science, and mathematics courses. In this respect, there is a balance between them, but sometimes they can be more abstract than other lessons." (T8)

When the course objectives are examined, it was ensured that many objectives from all grade levels are compatible with different disciplines. During the observations, it was indicated that in the educational situation of the teachers, the lesson provided harmony with various explanations and examples with both sub-branches and other disciplines, and in this respect, the principle of balance was achieved.

Table 12: Opinions on the Balance of the Curriculum in Terms of Allowing Different Learning Approaches

\begin{tabular}{lll} 
Theme & Category & Frequency \\
\hline
\end{tabular}




\begin{tabular}{lll}
\hline Allowing Different Learning & Allows Different Learning Approaches & 8 \\
\cline { 2 - 3 } Approaches & Not Allows Different Learning Approaches & 0 \\
\hline
\end{tabular}

According to the teachers' opinions, social studies lesson allows different learning approaches because it has different themes and different contents related to its sub-disciplines and many fields ( $\mathrm{f}=8$ ). Some of the teachers' opinions on this sub-problem are as follows:

"If we consider the social studies curriculum in our country with regards to citizenship transfer, social sciences and reflective thinking accordingly, it allows different learning approaches for structuring, prediction, and critical thinking dimensions." (T1)

"Social studies course is suitable for using different learning approaches as there are many learnings from life." (T4)

"The curriculum can help students gain different learning approaches in terms of the objectives and units within each theme." (T6)

In the curriculum, some objectives can be achieved by using different learning approaches, and in the observations made, it was found out that the principle of balance was achieved in terms of teachers trying to include different learning approaches in accordance with the course objectives and content.

Table 13: Opinions on the Balance of Curriculum Content in Terms of Appropriateness to Students' Development Level

\begin{tabular}{lrll}
\hline Theme & Category & Frequency \\
\hline The Appropriateness & of & Suitable for Student Development & 3 \\
\cline { 2 - 3 } Curriculum Content & to & Not Suitable for Student Development & 5 \\
Students' Development Level & & \\
\hline
\end{tabular}

According to the opinions of the teachers, the content of the social studies course is not suitable and balanced for the development level of the students because of the abstract subjects ( $\mathrm{f}=5$ ). During the observations, it was observed that some of the objectives in the curriculum remained abstract and used materials such as smartboards to concretize these objectives. Some of the teachers' opinions on this subproblem are as follows:

"The contents are suitable for the development of the students. In some subjects, for example, to fully understand the subject of selection and election, the 4th graders need to be addressed in more detail in terms of adopting democracy education and understanding." (T1)

"I think some subjects remain abstract because they are not suitable for the development level of the students." (T4)

"Absolutely not suitable. It needs to be simplified and the content divided into relevant areas. The transition between subjects and an emphasis on logic should be provided. For example, it is not very logical to teach Seljuk history after forests." (T5)

"Generally, I find it appropriate. However, the fact that some subjects are full of abstract concepts in the 4th grade makes learning difficult." (T6)

"There is a straight narration; only the use of maps is included as material. The use of more materials and tools should be included. We try to concretize the subjects with animations on the smartboard." (T8)

Table 14: Opinions on the Balance of the Curriculum in Terms of Being Open to Innovations and Being Tradition-Bound 


\begin{tabular}{lll} 
Being Open to Innovations & Being Open to Innovations & 3 \\
\cline { 2 - 3 } and Being Tradition-Bound & Being Tradition-Bound & 5 \\
\end{tabular}

According to the opinions collected from the teachers, the social studies curriculum is not balanced between innovation and tradition ( $\mathrm{f}=5$ ). The more traditional aspect of the curriculum prevails. Some of the teachers' opinions on this sub-problem are as follows:

"Our curriculum is not very open to innovations and put teachers into narrow forms. In this case, it brings along more traditionalism." (T1)

"I can say that there is a partial balance. The culture and heritage learning area is informative about traditions." (T3)

"I think it should be more open to innovations. It would be better if it covers the traditions of different cultures." (T4)

"It is more traditional as in all our curriculum." (T5)

"Although the curriculum is not completely dependent on innovation, adaptation studies to innovation do exist in recent years, although they are not very effective at this stage." (T6)

When the objectives in the social studies curriculum are examined, it can be said that a balance is tried to be ensured between innovation and traditionalism, but this situation cannot be achieved in the observations and teachers' opinions in practice, and in this sense, the principle of balance is violated.

Table 15: Opinions on the Balance of the Curriculum in Terms of Compliance with the Near and Far and Past and Current Developments

\begin{tabular}{lll}
\hline Theme & Category & Frequency \\
\hline \multirow{2}{*}{$\begin{array}{l}\text { Compliance with the Near } \\
\text { and Far and Past and Current }\end{array}$} & $\begin{array}{l}\text { Suitable for the Near and Far and Past and } \\
\text { Developments }\end{array}$ & 8 \\
\cline { 2 - 3 } & $\begin{array}{l}\text { Current Developments } \\
\text { Courrent Developments }\end{array}$ & \\
\hline
\end{tabular}

According to the opinions taken from teachers, the social studies curriculum established harmony and balance between the distant past and the current. Additionally, it was found that attention was paid to this principle in most of the acquired objectives $(\mathrm{f}=8)$. Some of the teachers' opinions on this subproblem are as follows:

"Social studies are not a field that varies much except the field of history. Advances in the technological field have some impact on the content of the curriculum. There is a balance between the distant past and the present in terms of updating." (T1)

"Near, far, and current time is included, but the logic can be taught more properly. However, it can still be considered sufficient. It can even be mentioned that the balance situation is good, especially in some subjects." (T5)

"The curriculum is a little more limited with the distant past, but there are harmony and balance with current developments." (T7)

\section{DISCUSSION, CONCLUSION AND SUGGESTIONS}

In this study, the social studies curriculum was evaluated according to the principle of balance, which is one of the guiding principles of curriculum development. As one of the curriculum theories, reductive theory explains the balance under conditions such as the laboratory where everything is fixed. However, educational curricula have a complex theory (Morrison, 2010). There is no one right or one answer to a situation. For this reason, data was collected and analysed through observation, interview 
and document analysis by making data triangulation in the study.

The social studies curriculum is more subject-centered than student-centered, especially due to the sequence and level of content, and the principle of balance could not be achieved in this sense. This may be due to the fact that the most crucial feature of the constructivist approach that it puts the student in the center is not fully reflected in the content. The teachers generally expressed that the content was too much on this subject and that the activities were less included. According to Demirtaş and Erdem (2015), one of the criticisms brought to the curriculum is that the content is too boring, and it supports this finding in this study. Another principle that the balance cannot be achieved in the curriculum is that the needs of the society in terms of the needs of students and society are prominent. Similarly, Yücel et al. (2017) found in their study that the balance principle was violated regarding students' interests and needs in the English language curriculum. Cuban (1992) stated that schools cannot find a solution to every problem of society and should not feel obliged to do so. The social studies course is a course that includes sub-disciplines such as history, geography, and citizenship. However, when the achievements are examined, it is stated that there is no balance in the field of history and that the field of history is more prominent based on the teachers' opinions, and the field of citizenship is given less space. This result is similar to Gürel's (2017) result that the discipline of history and geography comes to the fore in terms of sub-disciplines of the course in the social studies curriculum. All of the 131 objectives in the curriculum were examined, and it was determined that there was no balance in the distribution of the objectives in the cognitive, affective, and psychomotor areas, and during the observations, more cognitive goals were included. The teachers asserted that cognitive and affective goals were included in the curriculum, and psychomotor goals were almost non-existent. According to Ediger (2007) there should be a balance between knowledge, skills and attitudinal goals in terms of course objectives; otherwise, the student may have knowledge but cannot use it. Merter et al. (2012) stated that the 2011 secondary education English curriculum's targeted course hours were quite intensive, and the principle of balance was ignored. This finding may be closely related to the continuation of a success-oriented vision in education. It can be said that social studies lesson includes more group learning in terms of group and individualized learning. Teachers stated that the program is not suitable for individualized education because the students' interests, abilities, and needs are different in this sense. In the observations made, it was observed that the teachers, where the lessons were conducted mainly in groups, could not deal with students of different nationalities, especially because they did not know the language and did not have enough time and experience.

One of the basic elements of the curriculum is content. It must be balanced between the subjects and the logic of the students to provide the principle of balance in content. The principle of balance is to include a good variety of content to contribute to the development of the student (Tan, 2011). The teachers mentioned that the content remained too intensive and abstract due to the sub-disciplines of the course and that the balance could be achieved by reproducing the examples according to the students' economic, social and cultural environment. In this respect, it can be said that the content of the curriculum is determined by considering the logic of the subject. This finding coincides with the fact that the curriculum is subject-centered rather than student-centered in the first sub-problem for which an answer was found out. Taş and Kıroğlu (2018) asserted that the curriculum content is intense, which shows that the balance cannot be achieved in terms of content. In the study examining the balance between themes in the science curriculum in Lebanon, Boujaoude (2010) revealed that the curriculum violated the theme of "science as a way of knowing" and that there is no balance between themes. This finding is in the same directions as the result of the study. While preparing the curriculum, it is important to balance these differences by considering the characteristics of students with different intelligence types. When the curriculum objectives are examined, the characteristics of individuals with different intelligence types are considered, but in the observations made in practice, teachers adopt a standard approach more than students with average intelligence levels. In the interviews with the teachers, the 
teachers underlined that the curriculum was mostly aimed at students with average and high intelligence. In this context, the principle of balance for different intelligence types was violated. This finding also points out that inclusive education practices cannot be fully reflected in the curriculum.

The use of written, verbal, and visual techniques in the curriculum is one of the principles of balance. According to Ornstein and Hunkins (2014), it is essential to give appropriate weight to each of the different techniques while designing the curriculum to bring learners to their goals. When the objectives were examined and the observations made, it was determined that different written, verbal, and visual techniques were used by teachers. The teachers expressed that the balance was achieved by suggesting that the lesson was the most appropriate lesson in terms of using different written, verbal, and visual techniques. Some objectives in the curriculum, such as academic direction, sports, entertainment, and physical activities, were available, but in the observations of this study, it was seen that the academic side of the curriculum was prioritized. This may be due to the insufficient course time and physical facilities of the schools. A sufficient number of objectives are included in the course to enable in-class and out-of-class learning. In the interviews with the teachers, they suggested that the curriculum is balanced in this regard. However, out-of-class learning is primarily dependent on external factors such as parents, economy, and socio-culture. The observations determined that teachers try to realize out-ofclass teaching mostly through homework and activities. Besides, Jonyo and Jonyo (2019) emphasized the role of school principals to balance and supervise in-class and out-of-class learning.

The social studies course is closely related to many different disciplines in terms of its content, which has different sub-disciplines. When the objectives are examined, the balance of the course with different disciplines was achieved in many objectives at each grade level. The teachers stated that the course is especially compatible with Turkish and science disciplines. During the observations, it was determined that in the educational situation of the teachers, they established a relationship with both the sub-branches of the course and other disciplines by harmonizing them with various explanations and examples, and in this respect, the principle of balance was ensured. Bayır, Köse, and Balbağ (2016) stated in their study that benefiting from different disciplines in which teachers benefit from the intermediate disciplines of the lesson gives students various knowledge, skills, and values. Turan (2019) concluded that the social studies curriculum is associated with different disciplines at the level of learning areas. These results support the result of the study. Because of these features, it can be said that the course allows different learning approaches, and the principle of balance is implemented. In the curriculum, some objectives can be achieved by using different learning approaches, and in the observations made, it was observed that teachers included different learning approaches in accordance with the outcome and content, although not very diverse. The teachers stated that the lesson allows for different learning approaches because it has different themes and different contents related to their subdisciplines and many fields. A balance could not be achieved in terms of the compatibility of the content of the social studies course with the students' development levels. Hewitt (2006) also added that the balance between the developmental stages of learners and the complexity of the curriculum is important. It was determined that some of the objectives in the curriculum remained abstract, and the teachers mostly used smartboards to concretize them. On the contrary to this result, Geçitli and Bümen (2020) found out that the information technologies curriculum was trying to achieve the principle of balance by considering the students' age and development levels. The balance between being open to innovations and commitment to tradition could not be achieved in the curriculum. When the course outcomes are examined, it can be expressed that there is a balance between innovation and tradition only in the field of culture and heritage learning. Teachers stated that adaptation studies were carried out in the last curriculum and that they were insufficient at the moment and that the curriculum came to the fore with its traditionality. In the social studies curriculum, the balance was included in many objectives in terms of adaptation to the near and far past and current developments. Teachers indicated that both the past and current developments are included in the course content in the curriculum. 
Consequently, the principle of balance, which is one of the main principles of curriculum design, is provided in terms of the use of written, verbal, and visual techniques of the social studies curriculum, providing opportunities for in-class and out-of-class learning, the course being compatible with different disciplines, allowing different learning approaches, and adaptation to near and far past and current developments. Nevertheless, the balance is ignored for other principles.

\section{Suggestions:}

In light of the results obtained in the research, the following suggestions are made to ensure the principle of balance in the social studies curriculum:

\section{Suggestions for Curriculum Developers:}

1-The social studies curriculum is more subject-centered and was designed to appeal to the needs of society and the logic of the subject. Based on this background, it can be suggested that the student is more prominent and prepared in accordance with the logic of the student rather than the logic of the subject, by balancing their interests and needs with the needs of the society.

2-History, which is one of the sub-branches of social studies, is given more space in the content. It may be suggested to increase the content related to Geography and Citizenship and to establish a balance of content within the sub-branches.

3-Cognitive learning is prominent in terms of learning skills. Increasing the number of affective and psychomotor learning skills can be suggested to achieve a balance between these learning skills.

4-The curriculum was prepared to appeal to average and high-level students. Considering the lower level and other different students, it can be suggested to create a balance between different groups and make them suitable for individualized education.

5-It may be suggested to establish a balance between academic direction, sports, entertainment, and physical activities in the curriculum considering schools' facilities.

\section{Suggestions for Teachers:}

In light of the observations and findings made, the following suggestions can be made for teachers who are the implementers of the curriculum:

1-A balance between student- and teacher-centered education in lessons should be established.

2-A balance by including not only cognitive learning skills of students but also affective and psychomotor learning should be provided.

3-A balance should be ensured between students with different levels, cultures, and socio-economic characteristics in the courses, considering the inclusive education,

4-Based on the possibilities of the classroom, school, and environment, a balance should be implemented by appealing to many sensory organs of students such as academic aspects, sports, entertainment, and physical activity,

5-By using more than one learning method and technique in the lessons, suggestions can be made to establish a balance between the didactic and questioning learning of the students. 


\section{References:}

Adıgüzel, A. (2017). Program geliştirme süreci, Eğitimde Program Geliştirme ve Değerlendirme (Ed. Oral ve Yazar, 2017). Ankara: Pegem A Yayıncılık.

Akker, J.V.(2010) Curriculum design research, an introduction to educational design research, (Ed.Plomp, T \& Nieveen, N), SLO Netherlands institute for curriculum development

Aytaçlı, B. (2012) Durum çalışmasına ayrıntılı bir bakış, Adnan Menderes Üniversitesi Ĕ̆itim Fakültesi, Eğitim Bilimleri Dergisi, 3 (1), 1-9,

Bayır, Ö. G., Köse, T. Ç., \& Balbağ, N. L. (2016). Sosyal bilgiler dersinde ara disiplinlerden yararlanılmasına ilişkin öğretmen görüşleri, Anadolu Üniversitesi Eğitim Bilimleri Enstitüsü Dergisi, 6(2).

Boujaoude, S.(2002) Balance of scientific literacy themes in science curricula: The case of Lebanon, International Journal of Science Education, 24:2, 139-156, DOI: 10.1080/09500690110066494

Büyüköztürk, Ş., Kılıç Çakmak, E., Akgün, Ö.E., Karadeniz, Ş. \& Demirel, F. (2011), Bilimsel araştırma yöntemleri, Ankara: Pegem A Yayınları, 10.Ed.

Canlıer, D. \& Bümen, N.T.(2017). Yabancı dil ă̆ırlıklı beşinci sınıf ingilizce dersi öğretim programının program tasarım ilkeleri açısından analizi, Değişen Dünyada Eğitim (Ed. Dinçer, 2017) Ankara: Pegem A Yayıncilık.

Creswell, J. W. (2007). Qualitative inquiry \& research design: Choosing among five approaches USA: SAGE Publications. Retrieved June 7th, 2019 from https://books.google.com.tr/books?id=Ykruxor10cYC\&printsec=frontcover\&dq=Qualitative+Inq uiry+and+Research+Design:+Choosing+Among+Five+Approaches\&hl=tr\&sa=X\&ved=0ahUK EwiEx4TZstziAhWxwqYKHYhiDqUQ6AEIKTAA\#v=onepage\&q=CASE\%20STUDY\&f=fals

e

Çakmak, Z., Kaçar, T., \& Arıkan, İ. (2017). Sosyal bilgiler öğretmenlerinin ortaokul sosyal bilgiler dersi taslak öğretim programına ilişkin görüşleri, The Journal of Academic Social Science, 5(54), 576-597.

Demirtaş, Z. \& Erdem, S. (2015). Beşinci sınıf İngilizce dersi öğretim programı: Güncellenen programın bir önceki programla karşılaştırılması ve programa ilişkin öğretmen görüşleri, Sakarya University Journal of Education, 5(2), 55-80.

Doğanay, A. (2008). Öğretim ilke ve yöntemleri, Ankara: Pegem A Yayıncılık.

Ediger, M. (2007). Balance in the curriculum. College Student Journal, 41(2), 376+.

Galton, M.(2000) A national curriculum balance sheet, Education review, 15(2), 15 - 21.

Geçitli, E. \& Bümen, N. T. (2020). İlkokul ve ortaokulda bilişim teknolojileri alanında yer alan derslerin öğretim programları üzerine bir analiz: 1998-2018, Bolu Abant İzzet Baysal Üniversitesi Ĕ̈itim Fakültesi Dergisi, 20(4), 1912-1934. https://dx.doi.org/10.17240/aibuefd.2020.20.58249627376

Gürel, D. (2017). Taslak sosyal bilgiler öğretim programına yönelik yapısal bir değerlendirme, $I$. Uluslararası Sınırsız Eğitim ve Araştırma Sempozyumu (USEAS2017), 236-246.

Hewitt, T. (2006). In search of curriculum. In Understanding and shaping curriculum: What we teach and why (pp. 23-48). Thousand Oaks, CA: SAGE Publications

Jonyo, D., \& Jonyo, B. (2019). Curriculum supervision and implementation in Kenya: The role of secondary school heads. The European Journal Of Educational Sciences, 06(02). doi: 10.19044/ejes.v6no2a4

Kahn, M.A \& Law, L.S.(2015) An Integrative Approach to Curriculum Development in Higher, International Education Studies; 8(3)

Kılıç, S.(2015) Kappa Test, Journal of Mood Disorders, 5(3) 
Kibet, M.(2016) Balanced Curriculum in Schools, Retrieved June 7 th, 2019 from https://enezaeducation.com/balanced-curriculum-in-schools/

Küçükahmet, L. (2009). Program geliştirme ve ögretim (24. Rd). Ankara: Nobel Yayın. Merter, F., Kartal, Ş. \& Çağlar, İ. (2012). Ortaöğretim İngilizce dersi yeni öğretim programının öğretmen görüşlerine göre değerlendirilmesi Mehmet Akif Ersoy Üniversitesi Ĕ̈itim Fakültesi Dergisi, 1(23), 43-58.

Miles, M. B. \& Huberman, A.M. (1994). Qualitative data analysis: an expanded sourcebook. (2. rd), Calif. : SAGE Publications

Morrison, K. (2010), Complexity theory, school leadership and management: Questions for theory and practice; https://doi.org/10.1177/1741143209359711

Oliva, P.F. \& Gordon, W.R. (2018) Program geliştirme [Curriculum development] (Translate.Editor: Kerim Gündoğdu), Ankara: Pegem A Yayıncılık.

Ornstein, A.C. \& Hunkins F.P.(2014), Eğitim programı [Educational curriculum] (Translate: Asım Arı). Konya: Eğitim Yayınevi

Özçelik, D. A. (2010). Eğitim programları ve öğretim[Educational curriculum and teaching] (2. Ed.). Ankara: Pegem Akademi

Patton, M.Q. (2002). Qualitative research and evaluation methods (3rd Ed.). London: Sage Publications, Inc.

Porter, (1989) A curriculum out of balance: the case of elementary school mathematics, Educational Researcher, 18(5), pp. 9-15.

Posner, G. J. (1995). Analyzing the curriculum. New York: McGraw Hill.

Sözen, E. \& Ada, S. (2018) 2005 ve 2017 sosyal bilgiler dersi öğretim programlarının (sbdöp) karşılaştırılması E-ajelı (Anatolian Journal of Educational Leadership and Instruction), 6(1), 5371.

Squires, D.A.(2013) The balanced curriculum model: description and results, SAGE Open January-March 2013: 1-10

Şencan, H.(2005) Sosyal ve davranışsal ölçümlerde güvenirlik ve geçerlik, Ankara: Seçkin Yayınevi.

Tan, Ş. (2011). Öğretim ilke ve yöntemleri, 7.rd., Ankara: PegemA Yayıncılık.

Taş, H., \& Kıroğlu, K. (2018). 2017 İlkokul sosyal bilgiler dersi öğretim programı'nın öğretmen görüşlerine göre değerlendirilmesi İlköğretim Online, 17(2), 697-716.

Turan, S. (2019). 2018 Sosyal bilgiler dersi öğretim programının disiplinlerarası yapısının incelenmesi, Sosyal Bilgilerde Yenilikçi Araştırmalar Dergisi, 2(2), 166 - 190.

Yıldız, V.A. \& Kılıç, D. (2018). Sosyal bilgiler dersi öğretim programlarına ilişkin öğretmen görüşleri: bir meta-sentez çalışması, Atatürk Üniversitesi Sosyal Bilimler Enstitüsü Dergisi 22(Özel Say1), 2115-2127.

Yin, R.K. (2014). Case study methods: design and methods (5. Bask1). Thousand Oaks: Sage Pbc. Yücel, E., Dimici, K., Yıldız, B. \& Bümen, N.T (2017) Son 15 Y1lda Yayımlanan İlk ve Ortaöğretim İngilizce Dersi Öğretim Programları Üzerine Bir Analiz, Ege Eğitim Dergisi, (18) 2: 702-737 